\title{
Piospheric influence on forage species composition and abundance in semi-arid Karamoja sub-region, Uganda
}

Anthony Egeru ${ }^{1,2^{*}}$, Oliver Wasonga ${ }^{3}$, Laban MacOpiyo ${ }^{3}$, John Mburu' ${ }^{4}$, John R. S. Tabuti and Mwanjalolo G. J. Majaliwa ${ }^{5}$

\begin{abstract}
Piospheres in semi-arid areas are gradients of animal impacts around watering holes. Few studies have examined the impact dynamics of herbaceous and woody species composition and abundance in relation to piospheres in East Africa. In this study, we identified the trend in piosphere development, assessed piosphere use and change indicators, and identified herbaceous and woody plant structure in relation to piospheres in the Karamoja sub-region, Uganda. Results revealed that piosphere development has been reactionary to drought and/or insecurity events and increased rapidly in the last decade. A diversity of herbaceous and woody plants exists around the piospheres. Use and change indicators revealed high trampling and grazing intensity, high presence of erosion signs and low litter cover. Gradient distance had both positive and negative effects on trampling intensity, percent exposure and plant height, respectively. A negative and positive effect of gradient distance was also observed on different herbaceous and woody forage species leading to the identification of both increaser and decreaser species around the piospheres. Therefore, as concentrated use of the piospheres continues unabated, an outward ripple effect leading to loss and/or increase of undesirable herbaceous and woody species will be felt. This will have an impact on the composition and abundance dynamics of desirable forage species in the sub-region.
\end{abstract}

Keywords: Distance; Herbaceous; Protected kraals; Waterholes; Woody

\section{Background}

East Africa's pastoralists occupying semi-arid lands rely on the exploitation of native forage resources to sustain their livestock production. In these areas, water and forage are thus important resources (Awa et al. 2002). However, semi-arid regions are characterised with limitations of water and forage that often trigger crisis situations during extreme climatic events, in particular during a drought. The availability of any one of these resources at any given location in a semi-arid landscape will determine the level of herbivore influence on vegetation dynamics at both spatial and temporal scales (Yu and Wu 2010; Wesuls et al. 2013). The intensity of herbivore influence is dependent on the spatio-temporal patterns of foraging decisions (Landman et al. 2012). Proximity to water,

\footnotetext{
* Correspondence: egeru81@gmail.com

'Department of Environmental Management, Makerere University, P.O. Box 7062, Kampala, Uganda

${ }^{2}$ Regional Universities Forum for Capacity Building in Agriculture (RUFORUM), P.O. Box 16811, Kampala, Uganda

Full list of author information is available at the end of the article
}

topography and the availability of food have been identified as key determinants of foraging decisions at landscape level (Bailey and Provenza 2008; Ash et al. 2004). These foraging decisions have impacts on biological diversity because herbivore foraging affects various aspects of vegetation dynamics (Landman et al. 2012). Further, adaptive components such as deferred resting of grazing sites to protect forage plants during critical life stages are important in influencing vegetation dynamics (Linstädter et al. 2013).

In arid and semi-arid ecosystems, where standing surface water is scarce, the introduction of artificial watering sources has significant ecological effects (Brooks et al. 2006). This is because these artificial water sources introduce focused grazing and activity patterns around them (Andrew 1988). It is these activity patterns that introduce the disturbance gradient called ' $a$ piosphere' (Lange 1969). Thus, a piosphere is an indicator of the localized impact of grazing on vegetation and soils. It has a radiating zone of attenuating animal impact away from a concentrator such 
as water, mineral licks and bedding grounds among others (Washington-Allen et al. 2004). Piospheres can be created by both wild and domesticated animals (Brooks et al. 2006) and can be visualized as a hub, in which distances from the hub can be marked off with concentric rings. The space between the concentric rings will represent the available foraging area at that distance from the hub-water source (Derry 2004).

Piosphere influence resulting from activity gradients has been largely studied with a focus on large herbivores such as elephants (Landman et al. 2012; Sternberg 2012). Distance-dependent effects including declines in perennial plants and species richness as well as structural diversity of perennial plants have been observed (Brooks et al. 2006; Landman et al. 2012). Further, their influence on soil nutrients (Stumpp et al. 2005), landscape degradation (James et al. 1999), soil compaction and erosion (Mugerwa et al. 2014), and variation in biomass defoliation and trampling (Shahriary et al. 2012) has been observed. Also, changes in forage species composition with increased presence of unpalatable perennial shrubs beyond the zone of extreme degradation coupled with a decrease in the abundance of palatable native perennial grasses have been documented (James et al. 1999). Further, Hoshino et al. (2009) showed that vegetation changes along the grazing gradient are characterized with changes in cover of life forms, particularly perennial species being replaced by annual species in close proximity to the piospheres. Further, an ecological niche of vegetation communities with fast growth characteristics that are well adapted to intense and frequent grazing and are also associated with forage of high nutritional quality has been observed to flourish within the sacrifice zone around the water points (Moreno García et al. 2014).

Much as these studies have shown herbivore effects associated with piospheres, a dearth of information necessary to facilitate the management of piosphere impacts in Karamoja sub-region pertains. Information specific to the effects of piospheres created by domestic livestock is particularly important in the management of rangelands as they tend to create spatial patterns on an otherwise homogeneous vegetation (Adler and Hall 2005; Brooks et al. 2006). This is important in most semi-arid regions where piosphere development has been undertaken. In particular, information regarding the ecological effects of these piospheres on forage resources is lacking. Therefore, this study was set out to examine the effect of piospheres on forage species composition and abundance as indicators of their potential influence on forage dynamics in the sub-region. Specifically, this study was set out to (i) identify the trend in piosphere development and assess the status of use and change indicators, and (ii) identify herbaceous and woody plant structure in relation to piospheres in Karamoja sub-region.

\section{Materials and methods \\ Study area}

Located in northeastern Uganda (Fig. 1), Karamoja subregion is a semi-arid region characterized by unpredictable rainfall and high temperatures (Dyer et al. 2008; Mubiru 2010). The sub-region is dominated by savanna grasslands punctuated by isolated woodlands on the slopes and tops of mountains. The sub-region is dominated by ephemeral streams that flow east to west. Pastoral and agro-pastoral livestock herding forms the basis. The subregion's topography consists of a low-lying plateau, rolling plains and broad rolling to flat plains rising to an altitude of 1,000 to $1,440 \mathrm{~m}$ in most locations. The sub-region's soils are from the Precambrian basement complex and consist of sands, loamy sands of low water holding capacity and black cracking cotton clays-vertisols (Nakileza et al. 1999). Traditionally, the Karamojong obtained water from hand-dug wells, pans, ponds, ephemeral streams and shallow wells dug at the river beds. Livestock is grazed on native forages at local, landscape and regional scale depending on season, availability of pasture and water in the grazing landscapes.

\section{Piosphere mapping}

Piospheres were mapped using a hand-held Global Positioning System (GPS). The mapping exercise specifically targeted water sources for livestock including dams, pans, valley tanks and rock catchments as well as protected kraals. Protected kraals refer to night kraaling areas (locally known as bomas) where security is provided to herders by the Uganda Peoples Defense Forces (UPDF). The purpose is to protect the livestock of disarmed herders and warriors from armed rustlers. The mapping exercise was conducted in all the seven districts in the sub-region including Moroto, Kotido, Abim, Kaabong, Nakapiripirit, Napak and Amudat. Piosphere attributes (applicable to waterhole) including the year of construction were collected. Protected kraal attributes included number of livestock and duration of the kraal at the current location. Additional spatial data on water sources was obtained from the Humanitarian Response Common Operational Datasets-Fundamental Operational Datasets (COD-FOD) data registry (https:// cod.humanitarianresponse.info) of the United Nations Office for the Coordination of Humanitarian Assistance (UNOCHA). The data archived by the Humanitarian Response repository is a collection of data provided by UNOCHA obtained from different stakeholders working within northern Uganda. This data was essential in providing a comprehensive state of the spatial distribution of all water sources in Karamoja sub-region.

\section{Assessment of use and change indicators of piosphere}

In order to understand the state of waterhole and protected kraal piospheres, use and change indicators were 


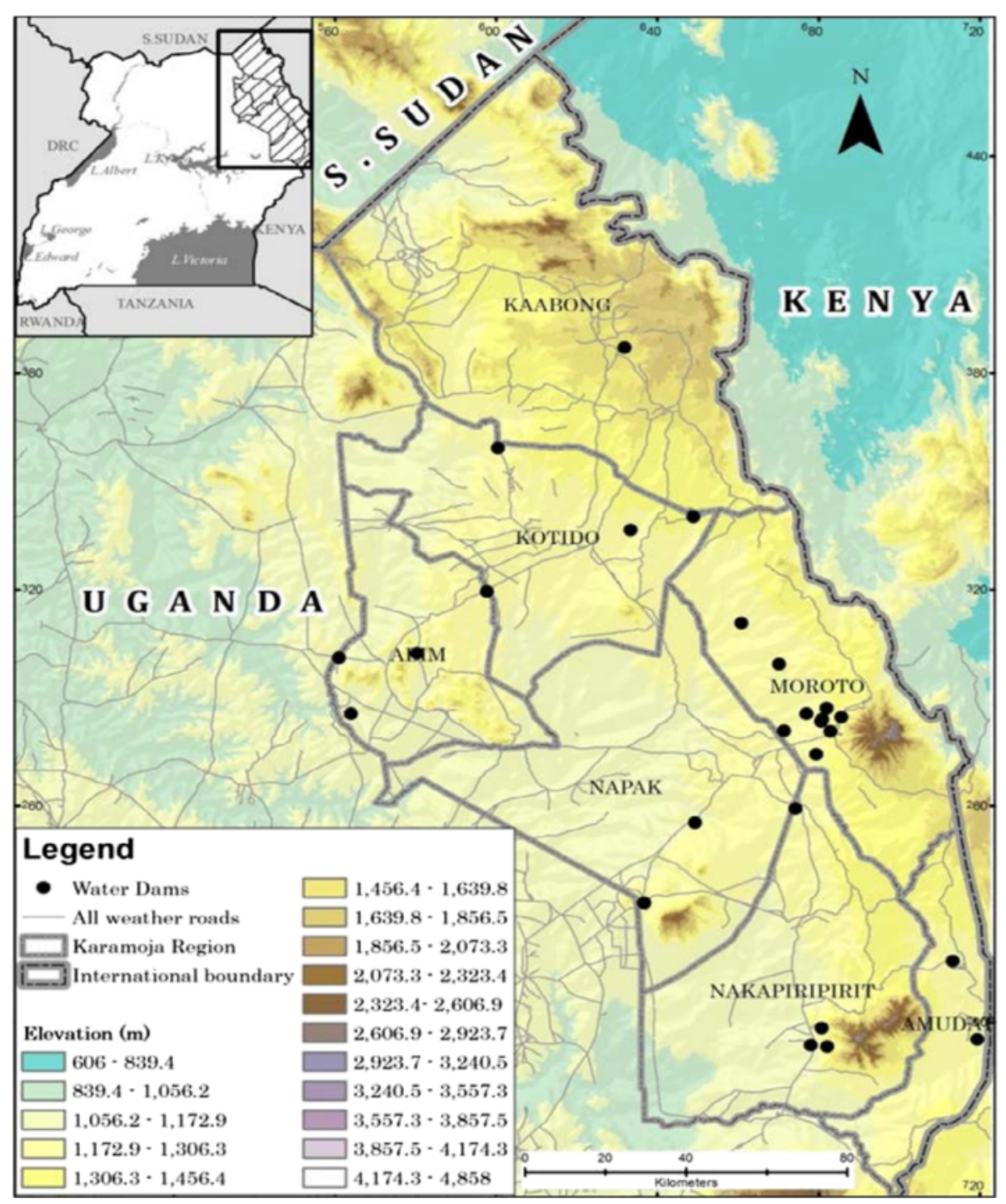

Fig. 1 Karamoja sub-region

assessed (Table 1). Use indicators that were assessed included trampling intensity and grazing intensity of both herbaceous and browse forage species. On the other hand, change indicators assessed included erosion features such as rills, gullies, pedestals, litter dams and soil surface hardness. This study adopted the Riginos and Herrick (2010) guidelines for rangeland health monitoring with few modifications.

\section{Effect of piospheres on forage species abundance}

Herbaceous forage species data was collected within and around piospheres (protected kraal and waterhole). A total of nine waterholes were assessed (considering the generally uniform topography and soil types), four replicates in each district (Moroto and Kotido). The choice of waterholes for monitoring depended on accessibility and security status
Table 1 Use and change indicators and the assessment criteria

\begin{tabular}{ll}
\hline Indicator & Likert \\
\hline Trampling intensity & Likert scale \\
& $\begin{array}{l}1=\text { very low, } 2=\text { low, } 3=\text { moderate, } \\
4=\text { high, } 5=\text { very high }\end{array}$ \\
& Likert scale \\
& $\begin{array}{l}1=\text { very low, } 2=\text { low, } 3=\text { moderate, } \\
\text { Percent exposure }\end{array}$ \\
& $\begin{array}{l}\text { Height } \\
\text { Plant height }\end{array}$ \\
Signs of erosion (gullies, & Dummy high \\
rills, litter dams, pedestals) & \\
Soil surface hardness & Likert \\
& $\begin{array}{l}1=\text { very soft, } 2=\text { soft, } 3=\text { moderately hard, } \\
4=\text { hard, } 5=\text { very hard }\end{array}$ \\
\hline
\end{tabular}


(briefing and clearance provided by the UPDF stationed near all major livestock water sources). We monitored four protected kraals including two in Kotido district, one in Moroto district and one in Nakapiripirit district, respectively. The protected kraals considered were those that had lasted at least two years in the same location.

A north-south and east-west transect approach was utilized. Each transect started $5 \mathrm{~m}$ away from the piosphere periphery (a piosphere periphery was defined as the edge of a waterhole rim-mound of soil that form sort of a barrier reef to provide for water accumulation) and stretched for a distance of $100 \mathrm{~m}$. Herbaceous species were assessed after every $25 \mathrm{~m}$ within a $1-\mathrm{m}$ nested quadrat. Available species were identified and tufts counted and recorded. On the other hand, woody species were assessed on a 5-m quadrat after every $25 \mathrm{~m}$; all species present were identified, counted and recorded. Owing to the ephemeral nature of the streams in the sub-region that make accessibility to the different areas unpredictable during the wet season, waterholes considered for assessment were within a 10- to $15-\mathrm{km}$-foot walking distance from a motorable road (in at least the worst condition when the roads were cut off). All species that could not readily be identified on-site were transported to Makerere University for identification.

\section{Data processing and analysis}

Piosphere spatial data recorded using the GPS was downloaded using MapSource software and processed in ArcGIS 10.1 from where piosphere spatial distribution maps were developed. Descriptive and trend statistics of piosphere development (1924 to 2012), piosphere use and change indicators were generated using XL-STAT. In determining the influence of grazing intensity on piosphere use and change indicators, we utilised distance from the piosphere as a proxy indicator of grazing intensity. Distance as a proxy indicator of grazing intensity in piosphere analysis has previously been applied by Thomas and Twyman (2004) and Wesuls et al. (2013) in the Kalahari and Namibia semi-arid areas, respectively. The effect of grazing intensity on use indicators (trampling intensity, plant height and percent exposure) was assessed by performing a generalized linear regression. Prior to undertaking a loglinear regression, we used principal component analysis (PCA) to explore how distance influences herbaceous and woody species composition distribution at the piospheres. Species whose eigenvectors had the lowest eigenvalues were generally excluded from further analysis in the loglinear regression because they had the least information about the species distribution at the piospheres. In assessing the effect of grazing intensity on herbaceous and woody species abundance (because species abundance were counts), a log-linear regression was applied; this is because both herbaceous and woody species data were count data and best analysed using a log-linear Poisson regression.
This method can deal with several difficulties inherent to observation data such as missing values, over- and under-sampling of particular strata, serial correlation and deviations from the Poisson distribution. Further, the method is capable of testing the effects of covariates on the changes so that the impact of activities on change can be investigated (Van Strien et al. 2004). Both generalized and log-linear regression analyses were performed in Gen-Stat 12th edition.

\section{Results}

Trends in piosphere development and spatial distribution Spatially, seven concentration zones of water sources were mapped in Karamoja sub-region (Fig. 2) with a total of 1,271 water sources with $58 \%$ of these being boreholes. Seventy-nine percent of the water sources documented were constructed in the last decade (2000 to 2012). Water sources purposely constructed for livestock constituted $11 \%$ of the total water sources in the sub-region. Three phases of water source construction were observed: the first phase (1924 to 1979), second phase (1980 to 1999) and third phase (2000 to 2012); these represented $4.3 \%$, $16.7 \%$ and $79 \%$ of the water sources constructed in the region, respectively (Fig. 3).

\section{Status of waterhole and protected kraal piospheres}

On average, a low litter cover and high grazing intensity were observed around both the waterhole and protected kraal piospheres. The soil around the waterholes were generally loose and detached (Table 2). Despite the pronounced presence $(86.3 \%)$ of erosion signs around the waterholes, there was differentiated presence of erosion indicators (rills, gullies, litter dams and pedestals). For example, rills were present in only $39.1 \%$ of the waterhole piosphere sampling plots. In the protected kraals, a low litter cover, high grazing intensity, high percent exposure, as well as presence of erosion indicators were observed. Compared to the waterholes, protected kraals depicted a very hard soil surface with a conspicuous absence of gullies (Table 3). The influence of grazing intensity on change indicators was tested using a generalized linear regression. Results showed that distance had a significant and positive influence on herbaceous plant height and grazing intensity as one moved away from the piosphere centre, the sacrifice zone (Table 4; also see Additional file 1: Figures A1 to A4). On the other hand, grazing intensity decreased outward.

\section{Herbaceous and woody species composition}

Thirty-four (34) and twenty-six (26) herbaceous grass species were recorded at the waterhole and protected kraal piospheres, respectively. In both the waterholes and protected kraals, Cynodon dactylon and Chloris pychnothrix were the most abundant species (Table 5). 


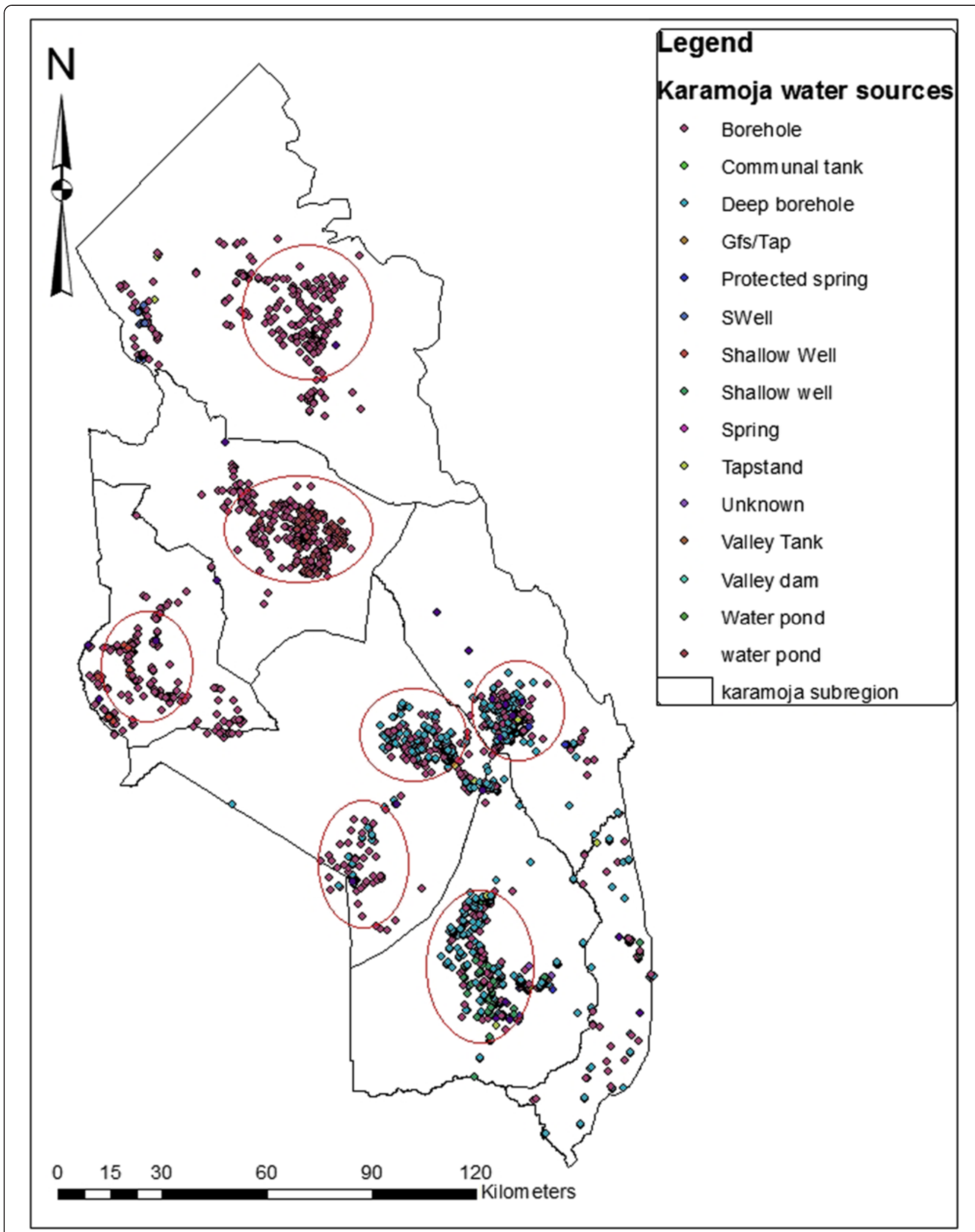

Fig. 2 Spatial distribution of water sources 


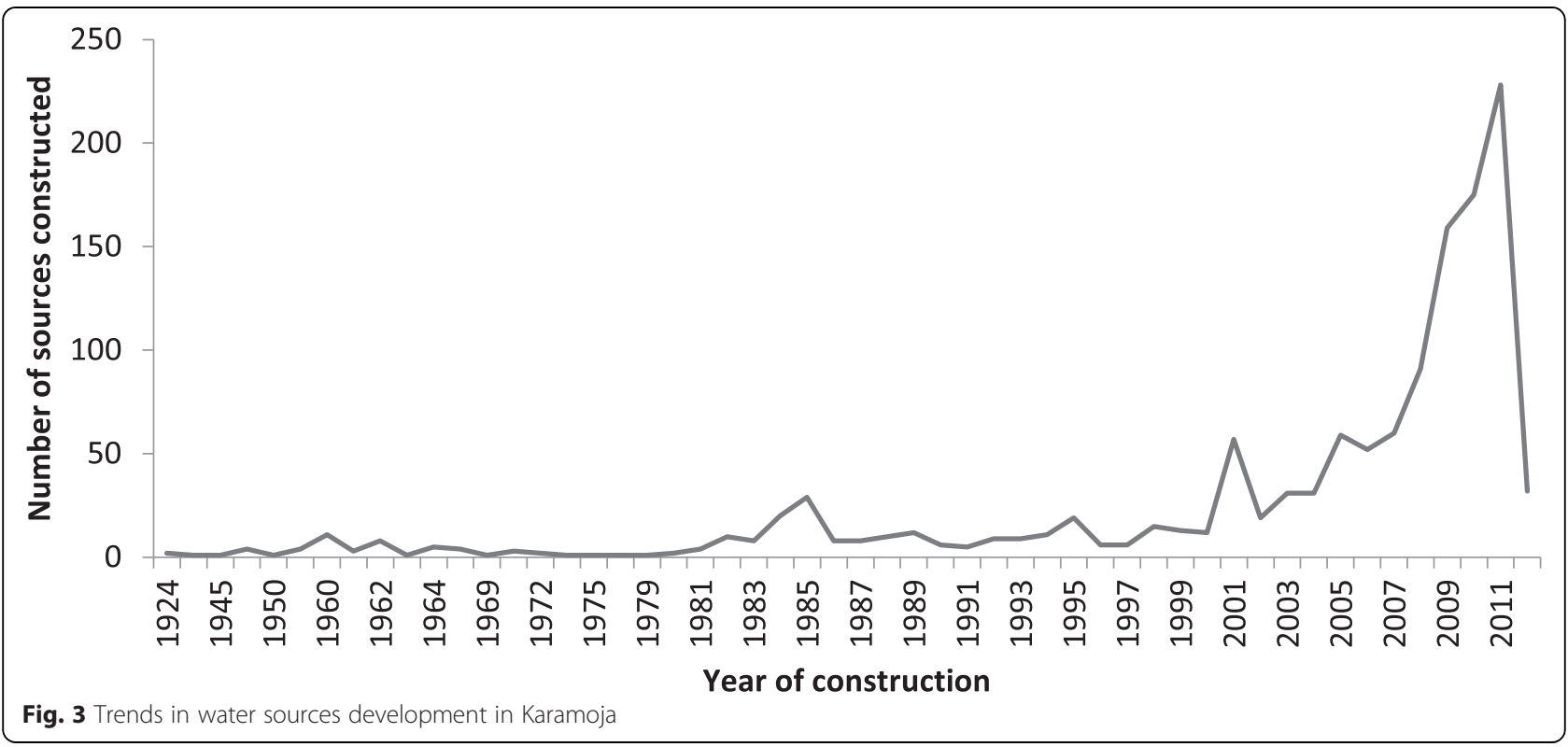

At the waterholes, we found Aristida adscensionis, Cynodon nlemfuensis, Hyparrhenia rufa, Oxytenanthera abyssinica and Cenchrus ciliaris to be the most abundant grass species. Meanwhile, Paspalm scrobiculatum, Melinis repens, Digitaria vellutina and Eleusine Coracana were the most abundant species observed around the protected kraals (Table 5). A total of 37 woody plants were identified at the waterhole piospheres (Table 6) with Triumfetta annua (14.3\%) and Indigofera erecta (3.8 \%) being the most abundant woody species observed. There were however additional 58 other plant species (herbs and forbs) that were observed around the waterholes (Table 6). Thirty-four woody species were observed around the protected kraals in Karamoja. We also documented additional 38 other plant species (herbs and forbs) at the protected kraals. Solanum incanum, Ormocarpum trichnocarpa and Lannea humilis had high abundance at the protected kraals (Table 7).

\section{Effect of piospheres on forage species abundance}

Results showed that gradient distance has a significant effect on species composition and abundance at both waterhole and protected kraal piospheres in Karamoja (Fig. 4a, b, c, d). Table 8 (waterholes) presents a summary of model results that revealed that herbaceous species Cynodon nlemfuensis, Hyparrhenia rufa, Aristida adscensionis, Oxytenanthera abyssinica, Hyparrhenia filipendula, Echinochloa haploclada, Chloris pychnothrix and Chloris virgata significantly increased with distance away from the waterhole piosphere (Table 8; also see Additional file 2: Figures B1 to B14). This pattern revealed increasing distance dependence thus showing that these species have decreaser forage species characteristic (species that increase with a decrease in grazing pressure). Meanwhile,
Cynodon dactylon, Hyparrhenia newtonii, Sporobolus pyrimidalis and Sporobolus stapfianus significantly decreased with an increase in gradient distance, thus indicative of increaser grass species.

Unlike with grass species, there were few woody species that were statistically significant at the waterhole piospheres (Table 9). Both positive and negative significant effects of gradient distance on forage species abundance in waterhole piospheres were observed (Additional file 3: Figures $\mathrm{C} 1$ to C7). Acacia xanthopholea was found to steadily establish itself as gradient distance from the focus increased. This trend was similarly observed with Acacia drepanolobium, Euphorbia spp., Maerua pseudopetalosa and Triumfetta annua (Table 9). This means that these woody plant species have increaser plant characteristics. On the other hand, species such as Acacia senegal and Cassia obtusifolia decreased as distance increased away from the piospheres.

Model results from the protected kraals revealed that Melinis repens and Panicum maximum significantly increased with gradient distance $(P \leq 0.05)$, indicating that their abundance increased away from the protected kraal focus. On the other hand, Cynodon dactylon, Brachiaria jubata and Echinochloa haploclada decreased with an increasing distance away from the protected kraals $(P \leq$ 0.05). Similarly, Sporobolus stapfianus, Eragrostis superba, Digitaria vellutina and Setaria spp. were significant and negatively influenced by distance. On the other hand, Pennisetum mezainum, Brachiaria platynota, Melinis repens and Chloris pychnothrix increased $(P \leq 0.05)$ away from the piosphere (Table 10; also see Additional file 4: Figures D1 to D16). Model results for woody species at the protected kraals showed that Acacia drepanolobium increased away from the protected kraal hubs while Solanum 
Table 2 Status of use and change indicators of waterhole piosphere

\begin{tabular}{|c|c|c|c|c|c|}
\hline \multirow[t]{2}{*}{ Use and change indicators } & \multicolumn{4}{|c|}{ Distance outward from the piosphere } & \multirow{2}{*}{$\begin{array}{l}\text { Overall } \\
\text { averag }\end{array}$} \\
\hline & $25 \mathrm{~m}$ & $50 \mathrm{~m}$ & $75 \mathrm{~m}$ & $100 \mathrm{~m}$ & \\
\hline \multicolumn{6}{|l|}{ Litter cover (\%) } \\
\hline Very low & 63.6 & 61.3 & 51.5 & 50.0 & 56.6 \\
\hline Low & 27.3 & 32.3 & 42.4 & 38.2 & 35.0 \\
\hline Moderately low & 9.1 & 6.5 & 6.1 & 11.8 & 8.3 \\
\hline \multicolumn{6}{|l|}{ Trampling intensity (\%) } \\
\hline Overall trampling intensity & 69.5 & 64.5 & 63.7 & 52.9 & 62.7 \\
\hline Very low & 0.0 & 0.0 & 0.0 & 0.0 & 0.0 \\
\hline Low & 16.1 & 0.0 & 3.2 & 11.8 & 7.8 \\
\hline Moderately low & 6.5 & 19.4 & 12.9 & 73.5 & 28.1 \\
\hline High & 67.7 & 74.2 & 74.2 & 14.7 & 57.7 \\
\hline Very high & 9.7 & 6.5 & 9.7 & 0.0 & 6.5 \\
\hline \multicolumn{6}{|l|}{ Soil surface hardness (\%) } \\
\hline Soft & 11.8 & 33.3 & 25.8 & 23.5 & 23.6 \\
\hline Moderately soft & 8.8 & 3.3 & 6.5 & 5.9 & 6.1 \\
\hline Hard & 14.7 & 13.3 & 9.7 & 17.6 & 13.8 \\
\hline Very hard & 20.6 & 23.3 & 16.1 & 11.8 & 18.0 \\
\hline Loose & 44.1 & 26.7 & 41.9 & 41.2 & 38.5 \\
\hline \multicolumn{6}{|l|}{ Erosion signs (\%) } \\
\hline Present & 93.9 & 75.8 & 87.1 & 88.2 & 86.3 \\
\hline Not present & 6.1 & 24.2 & 12.9 & 11.8 & 13.7 \\
\hline \multicolumn{6}{|l|}{ Rills (\%) } \\
\hline Present & 69.7 & 21.2 & 29.0 & 35.3 & 39.1 \\
\hline Not & 30.3 & 78.8 & 67.7 & 64.7 & 60.9 \\
\hline \multicolumn{6}{|l|}{ Gullies (\%) } \\
\hline Present & 24.2 & 21.2 & 24.2 & 35.3 & 26.4 \\
\hline Not present & 75.8 & 78.8 & 74.2 & 64.7 & 73.6 \\
\hline \multicolumn{6}{|l|}{ Litter dams (\%) } \\
\hline Present & 30.3 & 24.2 & 24.2 & 35.3 & 28.6 \\
\hline Not present & 69.7 & 75.8 & 74.2 & 64.7 & 71.4 \\
\hline \multicolumn{6}{|l|}{ Pedestals (\%) } \\
\hline Present & 18.2 & 12.9 & 9.7 & 20.6 & 15.3 \\
\hline Not present & 81.8 & 87.1 & 90.3 & 79.4 & 84.7 \\
\hline Percent exposure & 70.2 & 63.1 & 64.7 & 64.9 & 65.7 \\
\hline Plant height (m) & 0.4 & 0.6 & 0.8 & 0.9 & 0.7 \\
\hline
\end{tabular}

incanum decreased with an increase in gradient distance at the protected kraals (Table 11; also see Additional file 5: Figures E1 and E2).

\section{Discussion}

Trends in piosphere development and spatial distribution Waterhole development in Karamoja took three phases (1924 to 1979,1980 to 1999,2000 to 2012) with most of the current water sources constructed in the third phase. The first recorded water source development in the region was marked in 1924. According to Barber (1962), this appears to be the first colonial response to drought events in the region particularly emerging out of the late 1890s drought. These initial steps continued reaching the first peak period between 1948 and 1962. Knighton (2006) opined that in between 1924 and 1962, drought events were recorded in 1927 to 1930 and 1933 to 1934 . Further, a series of drought events (multi-year) were observed in 1939 and 1943 to 1946 . This period eventually came to be known as 'Lokwakoit' - white bones indicating the severe 
Table 3 Status of use and change indicators of protected kraal piosphere

\begin{tabular}{|c|c|c|c|c|c|}
\hline \multirow[t]{2}{*}{ Use and change indicators } & \multicolumn{4}{|c|}{ Distance outward from the piosphere } & \multirow{2}{*}{$\begin{array}{l}\text { Overall } \\
\text { average }\end{array}$} \\
\hline & $25 \mathrm{~m}$ & $50 \mathrm{~m}$ & $75 \mathrm{~m}$ & $100 \mathrm{~m}$ & \\
\hline \multicolumn{6}{|l|}{ Litter cover (\%) } \\
\hline Very low & 33.3 & 45.5 & 33.3 & 25.0 & 34.3 \\
\hline Low & 66.7 & 54.5 & 66.7 & 75.0 & 65.7 \\
\hline \multicolumn{6}{|l|}{ Trampling intensity (\%) } \\
\hline Overall trampling intensity & 100 & 100 & 90 & 75 & 91.3 \\
\hline High & 0 & 0 & 10 & 25 & 8.7 \\
\hline Very high & 100 & 100 & 90 & 75 & 91.3 \\
\hline \multicolumn{6}{|l|}{ Soil surface hardness (\%) } \\
\hline Hard & 27.3 & 27.3 & 33.3 & 41.7 & 32.4 \\
\hline Very hard & 63.6 & 63.6 & 58.3 & 50.0 & 58.9 \\
\hline Loose & 9.1 & 9.1 & 8.3 & 8.3 & 8.7 \\
\hline Percent exposure & & 80.6 & 85.2 & 83.9 & 78.3 \\
\hline Plant height (m) & 0.5 & 0.6 & 0.6 & 1.0 & 100 \\
\hline
\end{tabular}

Erosion signs, rills, gullies, litter dams and pedestals were present in all the protected kraals

drought that killed cattle in great numbers (Gray 2013). As a result, a drive for the construction of dams was launched in 1941, thus explaining the increase in the importance of artificial water sources in the region particularly between 1948 and 1962. Similarly, the second phase emerged out of continued response to drought events of the 1970s and early 1980s. Like other drought events, these were similarly observed to have led to considerable collapse of livestock herds and caused food shortages as well as famine in the sub-region (Gray et al. 2003).

Like the first and the second phases, the third phase coincides with the 1999/2000 and 2008/2009 drought events that led to severe water shortages and livestock losses (Sundal 2009; Mubiru 2010). However, the third phase had another dimension: it corresponded to the Government of Uganda (GoU) reactivation of the disarmament programme. It is important to note that disarmament initiatives had hitherto been undertaken in 1945, 1953, 1954, 1960, 1964, 1984 and 1987, albeit with minimal success to write about (Powell 2010). The reactivated disarmament programme in the 2000s came with a difference in that GoU operationalized the development of water for production and livestock, with the protected kraal system, as strategies to ensure safety of the disarmed communities and promotion of peace (Stites et al. 2007; GoU 2007). The GoU, desperate to avert crisis, rapidly developed water sources and similarly increased the number of protected kraals to accommodate the disarmed communities' livestock. This led to the observed exponential increase in the number of piospheres (both waterholes and protected kraals) in the region in the last decade. In addition, the entry of several development organizations (both local and international) into the region in the last decade further accelerated the construction of several water sources. Most of the development organizations and partners were shifting their operations from northern Uganda following the return of relative peace after the defeat of the Lord's Resistance Army (LRA) insurgents.

Meanwhile, the spatial clustering that was observed in this study is attributable to the tremendous number of boreholes that were drilled to provide domestic water rather than water for livestock and/or for production. This

Table 4 Effect of piospheres on use and change indicators

\begin{tabular}{|c|c|c|c|}
\hline Indicators & Equation of the model & $R^{2}$ & $P$ value \\
\hline \multicolumn{4}{|l|}{ Waterhole piospheres } \\
\hline Grazing intensity & $y=75.54-0.208 \times$ Distance & 0.863 & 0.07 \\
\hline Plant height (m) & $y=0.29+6.61 E-03 \times$ Distance & 0.994 & 0.003 \\
\hline \multicolumn{4}{|c|}{ Protected kraal piospheres } \\
\hline Grazing intensity & $y=112.53-0.34 \times$ Distance & 0.869 & 0.06 \\
\hline Plant height (m) & $y=0.33+5.40 E-03 \times$ Distance & 0.722 & 0.04 \\
\hline
\end{tabular}


Table 5 Relative abundance of grass species in the waterhole and protected kraal piospheres

\begin{tabular}{|c|c|c|c|}
\hline \multicolumn{2}{|l|}{ Waterhole } & \multicolumn{2}{|l|}{ Protected kraal } \\
\hline Grass species & Relative abundance & Grass species & Relative abundance \\
\hline Cynodon dactylon & 19.4 & Chloris pychnothrix & 13.7 \\
\hline Chloris pychnothrix & 12.1 & Cynodon dactylon & 13.1 \\
\hline Chloris virgata & 9.3 & Sporobolus stapfianus & 10.9 \\
\hline Aristida adscensionis & 7.3 & Bracharia jubata & 7.7 \\
\hline Cynodon nlemfuensis & 5.2 & Hyparrhenia newtonii & 6.6 \\
\hline Setaria sphaceata & 4.8 & Dactyloctenium aegyptica & 4.9 \\
\hline Sporobolus stapfianus & 4.8 & Panicum maximum & 3.8 \\
\hline Echinochloa haploclada & 4.8 & Brachiaria platynota & 3.8 \\
\hline Hyparrhenia filipendula & 3.6 & Harpachne schimperi & 3.8 \\
\hline Sporobolus pyrimidalis & 3.6 & Setaria spp. & 3.3 \\
\hline Hyparrhenia rufa & 2.4 & Pennisetum mezainum & 3.3 \\
\hline Oxytenanthera abyssinica & 2.4 & Hyparrhenia filipendula & 2.7 \\
\hline Pennisetum polystachion & 2 & Paspalum scrobiculatum & 2.7 \\
\hline Microcloa kunthii & 2 & Melinis repens & 2.7 \\
\hline Setaria pumila & 1.6 & Eragrostis superba & 2.2 \\
\hline Bracharia jubata & 1.6 & Digitaria vellutina & 2.2 \\
\hline Hyparrhenia newtonii & 1.2 & Loudetia simplex & 1.6 \\
\hline Dinebra retroflexa & 1.2 & Sporobolus pyrimidalis & 1.6 \\
\hline Pennisetum mezainum & 1.2 & Eragrostis ciliaris & 1.6 \\
\hline Ekoriebu* & 1.2 & Echinochloa haploclada & 1.6 \\
\hline Cynodon plectostachyas & 0.8 & Eleusine indica & 1.6 \\
\hline Cynodon polystachyus & 0.8 & Hyparrhenia cymbria & 1.1 \\
\hline Setaria verticilola & 0.8 & Loudetia kagerensis & 1.1 \\
\hline Cenchrus ciliaris & 0.8 & Chloris virgata & 1.1 \\
\hline Eragrostis cilliaris & 0.8 & Eleusine coracana & 0.5 \\
\hline Loudetia simplex & 0.8 & Microcloa kunthii & 0.5 \\
\hline Eleusine indica & 0.4 & & \\
\hline Echinochloa kunthii & 0.4 & & \\
\hline Digitaria gazensis & 0.4 & & \\
\hline Dactyloctenium aeygptica & 0.4 & & \\
\hline Sorghum arundinacea & 0.4 & & \\
\hline Panicum atrosanguineum & 0.4 & & \\
\hline Panicum maximum & 0.4 & & \\
\hline Portulaca oleracea & 0.4 & & \\
\hline
\end{tabular}

${ }^{*}$ A specie whose scientific name has not been identified

spatial clustering led to the disproportionate distribution of water sources in the sub-region, leading to high grazing intensity and localized degradation (Mugerwa et al. 2014). In addition, several water sources and protected kraals were developed in close proximity to settlements (manyattas) and croplands (personal observations). This also increased the concentration of locus zones with the piospheric concentration effect on grass and woody species gradually and rapidly evolving. It is generally acknowledged that while artificial water sources provide water for domestic stock, native and feral mammalian herbivores, they create grazing locus zones with differentiated impacts on vegetation cover (James et al. 1999). Further, when such developments become pronounced, they interfere with pastoral mobility; this was observed as herders barely move over long distances for extended periods in search of water and pasture. This is because their movements are now being controlled and defined by the locus of waterholes 
Table 6 Relative abundance of browse species in the waterhole piospheres

\begin{tabular}{|c|c|c|c|c|c|}
\hline Woody, herbs and forbs forage species & $\%$ & Other plant species & $\%$ & Other plant species & $\%$ \\
\hline Triumfetta annua & 14.3 & Cyathula orthacantha & 10.0 & Corchorus olitorius & 0.1 \\
\hline Ipomea kituiensis & 5.4 & Lactuca capensis & 6.1 & Cucumis figarei & 0.0 \\
\hline Indigofera erecta & 3.8 & Scleria spp. & 3.8 & Ocinia trilobata & 0.0 \\
\hline Ocimum canum & 3.7 & Vernonia poskeana & 2.9 & Conyza florbeuda & 0.0 \\
\hline Solanum incanum & 3.3 & Kalanchoe lanceolata & 2.6 & Euphorbia candlebrum & 0.0 \\
\hline Maerua pseudopetalosa & 3.1 & Euphorbia (Louro) & 2.6 & Urena lobata & 0.0 \\
\hline Acacia nilotica & 3.1 & Senseveria robusta & 2.3 & Glinus oppositifolius & 0.0 \\
\hline Cassia obtusifolia & 3.1 & Hygrophilia auriculata & 2.1 & Hibiscus micranthus & 0.0 \\
\hline Acacia xanthopholea & 2.2 & Minuta tagetes & 2.0 & Podocarpus falcalus & 0.0 \\
\hline Acacia drepanolobium & 1.6 & Leucas martinicensis & 1.7 & Asystasia gigantica & 0.0 \\
\hline Justicia flavus & 1.5 & Abutilon hirtum & 1.2 & Senecio abyssinica & 0.0 \\
\hline Cassia obtusifolia & 1.2 & Euphorbia prostrata & 1.2 & Gamophocarpus frutecosum & 0.0 \\
\hline Balanite aegyptica & 0.9 & Leonotis nepetifolia & 0.8 & Barleria submollis & 0.0 \\
\hline Commelina benghalensis & 0.9 & Hibiscus micranthus & 0.8 & Amaranthus spp & 0.0 \\
\hline Vigna membranacea & 0.6 & Dombeya burgessiae & 0.4 & Nesea auriculata & 0.0 \\
\hline Flueggea virosa & 0.6 & Hibiscus serpens & 0.4 & Tamarindus indica & 0.0 \\
\hline Sida cordifolia & 0.5 & Acanthospermum hispidium & 0.4 & Ruellia patula & 0.0 \\
\hline Cissus quadrangularis & 0.5 & Sesamum agustifolium & 0.4 & Achyranthes aspera & 0.0 \\
\hline Sesbania sesban & 0.4 & Crotalaria spp & 0.3 & Hypoestes forskahlii & 0.0 \\
\hline Dichrostachys cinerea & 0.4 & Oxygonum sinuatum & 0.3 & Jasminium abyssinica & 0.0 \\
\hline Cadaba farinosa & 0.3 & Alternanthera sessilis & 0.2 & Cyanotis arachnoidea & 0.0 \\
\hline Ormocarpus trichocarpa & 0.3 & Asystasia somalensis & 0.2 & & \\
\hline Sida cuneifolia & 0.3 & Seseveria gigantea & 0.2 & & \\
\hline Acacia Senegal & 0.2 & Barleria submollis & 0.2 & & \\
\hline Asparagus flagellaris & 0.2 & Cyphostemma serpens & 0.2 & & \\
\hline Cordia sinensis & 0.2 & Aloe rwenzonrensis & 0.2 & & \\
\hline Acacia mellifera & 0.2 & Crossandra subacaulis & 0.2 & & \\
\hline Commiphora africana & 0.2 & Solanum cordifolia & 0.1 & & \\
\hline Acacia sieberiana & 0.1 & Solanum anguivi & 0.1 & & \\
\hline Balanite grabra & 0.1 & Portulaca oleracea & 0.1 & & \\
\hline Grewia holstii & 0.1 & Orbea dummeri & 0.1 & & \\
\hline Acacia oerfota & 0.1 & Otiophora pauciflora & 0.1 & & \\
\hline Aeschynomene indica & 0.1 & Hibiscus calyphyllus & 0.1 & & \\
\hline Desmodium tortuosum & 0.0 & Hibiscus abyssinicus & 0.1 & & \\
\hline Lannea humilis & 0.0 & Methalinia vlutina & 0.1 & & \\
\hline Commelina difusa & 0.0 & Sphaeranthui gomphrenoides & 0.1 & & \\
\hline Caparis tormentosa & 0.0 & Achyranthera aspera & 0.1 & & \\
\hline
\end{tabular}

and the potential for erecting protected kraals in the region. However, reducing the mobility of people and herds in response to environmental stress tends to promote high grazing pressure around the locus as well as undermining local strategies that facilitate recovery of the rangelands during drought intervals (Gray et al. 2003).

\section{Status of waterhole and protected kraal piospheres}

In this study, a high grazing intensity, high percent exposure and low litter cover were observed around the waterholes and protected kraals. The high percent exposure and low litter cover are attributable to the high grazing and trampling effect observed around the piosphere. These 
Table 7 Relative abundance of browse species in the protected kraal piospheres

\begin{tabular}{|c|c|c|c|}
\hline Woody, herbs and forbs forage plants & Relative abundance (\%) & Other plant species & Relative abundance (\%) \\
\hline Solanum incanum & 7.7 & Vernonia poskeana & 5.4 \\
\hline Ormocarpum trichocarpa & 4.0 & Ocimum canum & 4.0 \\
\hline Lannea humilis & 3.0 & Leucas martinicensis & 3.4 \\
\hline Cadaba farinosa & 2.7 & Dombeya burgessiae & 3.0 \\
\hline Asparagus flagellaris & 2.7 & Acanthospermum hispidium & 2.7 \\
\hline Cassia obtusifolia & 2.7 & Crossandra subacaulis & 2.3 \\
\hline Grewia villosa & 2.3 & Pavonia arabicum & 2.3 \\
\hline Zanthoxylum chalybeum & 2.3 & Aspilia mossambicensis & 1.7 \\
\hline Grewia mollis & 1.7 & Portulaca oleracea & 1.7 \\
\hline Grewia holstii & 1.7 & Amaranthus hybridus & 1.3 \\
\hline Maerua decumbens & 1.7 & Alternanthera sessilis & 1.3 \\
\hline Triumfetta annua & 1.7 & Tridax procumbens & 1.0 \\
\hline Sida cordifolia & 1.7 & Abutilon hirtum & 1.0 \\
\hline Balanite aegyptica & 1.3 & Cyathula orthacantha & 1.0 \\
\hline Solanum taitense & 1.3 & Lantana trifolia & 1.0 \\
\hline Acacia nilotica & 1.3 & Crotalaria pychnostacys & 1.0 \\
\hline Indigofera erecta & 1.3 & Elephantopus scaber & 1.0 \\
\hline Acacia drepanolobium & 1.0 & Lactuca capensis & 0.7 \\
\hline Commiphora africana & 1.0 & Oxygonum sinuatum & 0.7 \\
\hline Acacia xanthopholea & 1.0 & Euphorbia tircalli & 0.7 \\
\hline Cordia sinensis & 1.0 & Coccinia trilobata & 0.7 \\
\hline Rhus kwangoensis & 1.0 & Cyanotis arachnoidea & 0.7 \\
\hline Vigna membranacea & 1.0 & Oldenlandia herbacea & 0.7 \\
\hline Commelina benghalensis & 1.0 & Justicia flavus & 0.3 \\
\hline Ipomea kituiensis & 1.0 & Hibiscus micranthus & 0.3 \\
\hline Maerua pseudopetalosa & 1.0 & Pentanisia ouranogyne & 0.3 \\
\hline Acacia senegal & 0.7 & Hygrophilia auriculata & 0.3 \\
\hline Balanite gabra & 0.7 & Orthisiphon spp & 0.3 \\
\hline Ximenia americana & 0.7 & Otiophora pauciflora & 0.3 \\
\hline Acacia oerfota & 0.7 & Euphorbia candlebrum & 0.3 \\
\hline Acacia mollisima & 0.7 & Heliotropium steudneri & 0.3 \\
\hline Cleome gynandra & 0.7 & Crotalaria aculeata & 0.3 \\
\hline Gymnema sylvestre & 0.3 & Hibiscus diversifolius & 0.3 \\
\hline \multirow[t]{5}{*}{ Sesbania sesban } & 0.3 & Hypoxis obtusifolia & 0.3 \\
\hline & & Conyza floribunda & 0.3 \\
\hline & & Corchorus olitorius & 0.3 \\
\hline & & Stachterpheta spp & 0.3 \\
\hline & & Tagetes minuta & 0.3 \\
\hline
\end{tabular}

findings corroborate those of Dune et al. (2011) who established that trampling reduced plant cover, biomass and, at the highest rate, plant regeneration. It further exacerbated soil loss as a result of reduced vegetation cover and disturbed surface layers. The disturbed surface soil layers with loose soils were similarly documented in this study and could be attributed to the convergence effect of livestock from different kraals at the waterholes. Thus, the disturbed loose soil surface at the waterhole piospheres could help account for the observed erosion gullies. However, in the protected kraals, soil surface layers were generally very compact. This difference 


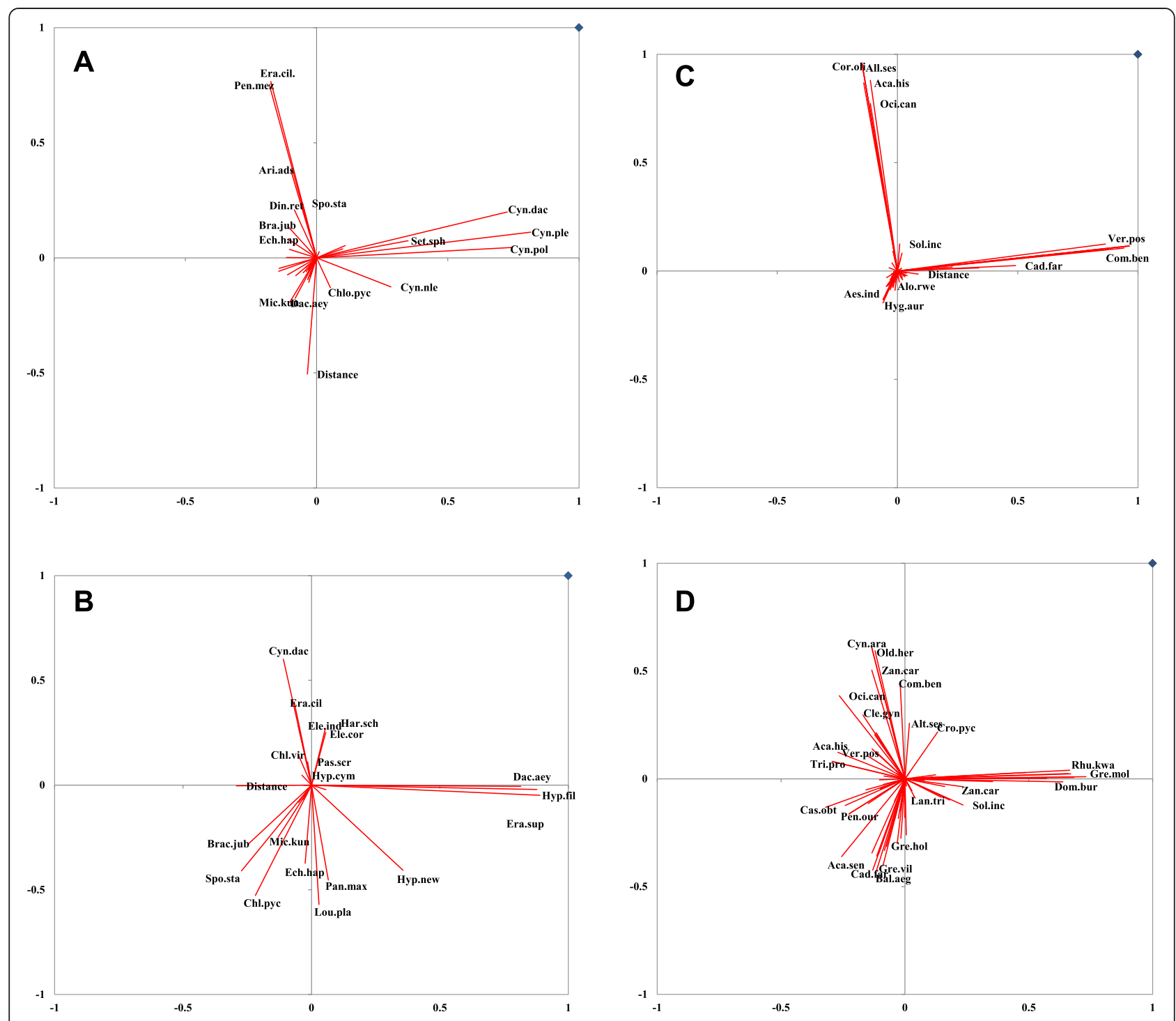

Fig. 4 a PCA of grass species at the waterholes. b PCA of grass species at the protected kraals. $\mathbf{c}$ PCA of woody species at the waterholes. $\mathbf{d}$ PCA of woody species at the protected kraals

Table 8 Waterhole piosphere effect on grass species

\begin{tabular}{llll}
\hline Herbaceous species & Equation of the model & $r$ & Chi pr \\
\hline Hyparrhenia filipendula & $\operatorname{Ln}(y)=1.818+0.029 \times$ Distance & 0.983 & 0.001 \\
Sporobolus pyrimidalis & $\operatorname{Ln}(y)=3.592-0.013 \times$ Distance & 0.905 & 0.001 \\
Sporobolus stapfianus & $\operatorname{Ln}(y)=4.431-0.015 \times$ Distance & 0.878 & 0.001 \\
Hyparrhenia rufa & $\operatorname{Ln}(y)=2.027+0.009 \times$ Distance & 0.911 & 0.044 \\
Oxytenanthera abyssinica & $\operatorname{Ln}(y)=0.207+0.043 \times$ Distance & 0.980 & 0.001 \\
Echinochloa haploclada & $\operatorname{Ln}(y)=2.855+0.018 \times$ Distance & 0.891 & 0.001 \\
Chloris virgata & $\operatorname{Ln}(y)=2.551+0.032 \times$ Distance & 0.967 & 0.001 \\
Cynodon dactylon & $\operatorname{Ln}(y)=6.021-0.026 \times$ Distance & 0.888 & 0.001 \\
Chloris pychnothrix & $\operatorname{Ln}(y)=3.525+0.018 \times$ Distance & 0.948 & 0.001 \\
Aristida adscensionis & $\operatorname{Ln}(y)=2.962+0.008 \times$ Distance & 0.930 & 0.006 \\
Cynodon nlemfuensis & $\operatorname{Ln}(y)=2.432+0.028 \times$ Distance & 0.963 & 0.001 \\
\hline
\end{tabular}

between waterhole and protected kraal piospheres could be attributed to variation in soil types and locations where the different piospheres are established. For example, protected kraals were generally located on raised lands with sandy loam soils while waterholes were situated on low-lying areas dominated by black cotton clay soils.

Table 9 Waterhole piosphere effect on woody species

\begin{tabular}{llll}
\hline Browse species & Equation of the model & $r$ & Chi pr \\
\hline Triumfetta annua & $\operatorname{Ln}(y)=2.805+0.006 \times$ Distance & 0.927 & 0.05 \\
Ocimum canum & $\operatorname{Ln}(y)=3.761-0.0228 \times$ Distance & 0.883 & 0.001 \\
Acacia xanthopholea & $\operatorname{Ln}(y)=0.16+0.0131 \times$ Distance & 0.941 & $0.06^{*}$ \\
Acacia senegal & $\operatorname{Ln}(y)=2.018-0.019 \times$ Distance & 0.900 & $0.08^{*}$ \\
Maerua pseudopetalosa & $\operatorname{Ln}(y)=0.187+0.026 \times$ Distance & 0.960 & 0.001
\end{tabular}

*Significant at $10 \%$ 
Table 10 Protected kraal piosphere effect on grass species

\begin{tabular}{|c|c|c|c|}
\hline Herbaceous species & Equation of the model & $r$ & Chi pr \\
\hline Panicum maximum & $\operatorname{Ln}(y)=3.972+0.006 \times$ Distance & 0.926 & 0.001 \\
\hline Sporobolus stapfianus & $\operatorname{Ln}(y)=1.778-0.012 \times$ Distance & 0.935 & 0.022 \\
\hline Cynodon dactylon & $\operatorname{Ln}(y)=5.115-0.003 \times$ Distance & 0.907 & 0.036 \\
\hline Bracharia jubata & $\operatorname{Ln}(y)=3.765-0.009 \times$ Distance & 0.896 & 0.009 \\
\hline Eragrostis superba & $\operatorname{Ln}(y)=6.699-0.0519 \times$ Distance & 0.900 & 0.001 \\
\hline Eragrostis ciliaris & $\operatorname{Ln}(y)=3.365-0.014 \times$ Distance & 0.890 & 0.006 \\
\hline Echinochloa haploclada & $\operatorname{Ln}(y)=5.764-0.042 \times$ Distance & 0.889 & 0.001 \\
\hline Digitaria vellutina & $\operatorname{Ln}(y)=4.045-0.033 \times$ Distance & 0.882 & 0.001 \\
\hline Pennisetum mezainum & $\operatorname{Ln}(y)=0.632+0.035 \times$ Distance & 0.971 & 0.001 \\
\hline Melinis repens & $\operatorname{Ln}(y)=1.339+0.023 \times$ Distance & 0.955 & 0.001 \\
\hline Chloris pychnothrix & $\operatorname{Ln}(y)=4.296+0.0063 \times$ Distance & 0.925 & 0.001 \\
\hline Hyparrhenia newtonii & $\operatorname{Ln}(y)=3.612+0.013 \times$ Distance & 0.937 & 0.001 \\
\hline Hyparrhenia filipendula & $\operatorname{Ln}(y)=4.649-0.031 \times$ Distance & 0.838 & 0.001 \\
\hline Loudetia simplex & $\operatorname{Ln}(y)=-2.461+0.093 \times$ Distance & 0.994 & 0.001 \\
\hline Brachiaria platynota & $\operatorname{Ln}(y)=4.429+0.004 \times$ Distance & 0.921 & 0.011 \\
\hline Dactyloctenium aegyptica & $\operatorname{Ln}(y)=2.964-0.032 \times$ Distance & 0.882 & 0.002 \\
\hline
\end{tabular}

This pattern has been previously documented by Oba (2012) in a study among the Matheniko of Karamoja sub-region.

Unlike Sasaki et al. (2008) and Smet and Ward (2006) who observed that grazing-affected parameters respond in a nonlinear manner to distance, we found a strong and positive linearized response to distance. Our results corroborate the findings of Manthey and Peper (2010) who noted that within the first few metres, strong piosphere changes are detectable with strong linearized predictions that effectively describe the piosphere concept (Macchi and Grau 2012) that has similarly been observed in this study. Grazing intensity was observed to gradually decrease away from the piosphere as the herbaceous plant height increased away from the piosphere. This also corroborates the findings of Shahriary et al. (2012) who observed in the Iranian piospheres that height of palatable species increased significantly with distance from watering points. It has hitherto been observed that a piosphere consists of a 'sacrifice zone' directly at the hotspot that is free of vegetation. This zone is subsequently followed by a transition zone that shifts nearly homogenously to a grazed zone. This grazed zone merges gradually into undisturbed natural vegetation that is hardly influenced by grazing (Manthey and Peper 2010). While the piosphere

Table 11 Protected kraal piosphere effect on woody species

\begin{tabular}{lllc}
\hline Herbaceous species & Equation of the model & $R^{2}$ & $P \leq 0.05$ \\
\hline Acacia drepanolobium & $\operatorname{Ln}(y)=0.460+0.028 \times$ Distance & 0.963 & 0.001 \\
Solanum incanum & $\operatorname{Ln}(y)=2.573-0.013 \times$ Distance & 0.891 & 0.007 \\
\hline
\end{tabular}

zone has been depicted to be devoid of vegetation; this assertion was relatively feasible in the protected kraals piospheres. On the other hand, we observed a gradual pattern with the sacrifice zone having low vegetation but gradually improving outward as has been previously articulated by several authors (Andrew 1988; Tarhouni et al. 2010; Manthey and Peper 2010). According to Macchi and Grau (2012), piospheres represent rather paradoxical landscape patterns, where the supply of the key limiting factor in an ecosystem (in the case of this study, water and security in the protected kraals) results in biomass reduction and overall ecosystem degradation.

\section{Effect of piospheres on herbaceous and woody species abundance}

This study observed a relatively high number of grass and woody species at waterholes and the protected kraals in Karamoja. This pattern could be attributed to (i) location differences, with waterholes being located at low-lying areas; (ii) convergence of livestock grazed in different landscapes leading to a pool of different species; and (iii) differences in plant resistance to piospheric effects including trampling, soil compaction and grazing intensity. According to Sternberg (2012), herder influences on pasture conditions can be obtained at piospheres; this is because livestock helps to shape piosphere dynamics in addition to other distinctive processes in the drylands. Plant species richness and density have been observed to vary with the piosphere type, size and distance from the grazing hotspot. For example, Zemmrich et al. (2007) established distance- 
plant density dependence in western Mongolia. Our results also corroborate with the findings of Teka et al. (2013) and Rajabov (2009) who observed differences in herbaceous species abundance and density along the gradient in Southern Ethiopia and in the piospheres of Uzbekistan, respectively. We observed that Cynodon dactylon had a high relative abundance in both the waterhole and protected kraal piospheres. Cynodon dactylon has been observed to be extremely tolerant to heavy grazing and withstand severe fires, adaptable to various soils and climate regimes, and is tolerant to salinity and flooding (Rita et al. 2012). Like Cynodon, Chloris pychnothrix, Sporobolus stapfianus belong to the Chloridoideae species group (Barboni et al. 2007). These species have been known to occur in abundance in heavily as well as lightly grazed grasslands (Abule et al. 2005). Further, Stride (1997) observed that these grasses also tend to increase near watering points because they are in a position to withstand severe over-grazing (Abule et al. 2007). Thus, this study's results are in agreement with such observations. We however note that a number of herbaceous species had a low abundance observed at the piospheres, indicating their limited ability to flourish in high grazing pressure.

Piosphere patterns are always detected in herbaceous species composition (Thrash and Derry 1999), and the species response to grazing is often varied (Wesuls et al. 2013). This study has shown differentiated species response to piosphere grazing. For example, some herbaceous species such as Aristida adscensionis, Chloris pychnothrix, Chloris virgata, Cynodon nlemfuensis, Echinochloa haploclada and Hyparrhenia filipendula increased away from the piosphere. This finding corroborates the findings of Zemmrich et al. (2007) in western Mongolia who established that as grazing pressure decreased, plant density per plot increased away from the zone of maximum grazing. It further corroborates the findings of Landsberg et al. (2002) who observed that watering points had a predominantly negative effect on species abundance on a regional scale. Decreasing trends in species with increasing proximity to watering points have been observed by several studies (Brooks et al. 2006; Todd 2006). Some of these species such as Aristida adscensionis have been identified by Abule et al. (2007) as less desirable grass species found in disturbed areas and indicative of poor rangeland condition.

On the other hand, herbaceous species such as Sporobolus stapfianus, Sporobolus pyrimidalis, Cenchrus ciliaris, Brachiaria jubata, Dactyloctenium aegyptica, Eragrostis cilliaris, Echinochloa haploclada, Digitaria vellutina and Cynodon dactylon decreased with distance away from the piosphere. This finding contrasts with the findings of Fusco et al. (1995) in which Sporobolus spp. was found to increase as distance from the waterhole increased. Similarly, Thrash and Derry (1999) noted that Cynodon dactylon has been observed to increase away from the piosphere. However, our results corroborate the earlier findings of Mansour et al. (2012) and Oluwole et al. (2008) who observed that species such as Eragrostis spp. and Sporobolus spp. are often considered as increaser II species; these species increase in abundance when the rangeland is over-utilised (Du Toit 2009). Our findings corroborate these earlier findings because herbaceous forage species Eragrostis superba, Eragrostis ciliaris, Sporobolus stapfianus and Sporobolus pyrimidalis were in close proximity to the piosphere. These species have previously been used as indicator species of rangeland degradation. For example, Mansour et al. (2012) discussed that rangeland condition can be classified using these increaser species; thus moderate condition can be identified using increaser I (e.g. Hyparrhenia spp.); poorincreaser II (e.g. Eragrostis spp. and Hyparrhenia spp.); and highly degraded-increaser III (e.g. Aristida spp.). This study has shown the existence of all these species in the piospheres of Karamoja, indicating existence of multiple states at the piospheres. The existence of increaser I (increase in abundance with under-utilization, e.g. Hyparrhenia filipendula, Hyparrhenia rufa) and increaser III (increase in abundance in areas that are selectively grazed, e.g. Aristida adscensionis) species in the study area can be explained by the observed variation in piosphere status. It is important to note that increaser III species such as Aristida adscensionis were only observed around the waterhole piospheres.

Differentiated occurrence of woody species with both increasing and decreasing patterns with proximity to and away from the piosphere was observed in this study. The increase of Acacia drepanolobium, Acacia xanthopholea, Maerua pseudopetalosa and Aspilia mossambicensis away from the locus could be attributed to rapid regeneration ability that these woody species have after the establishment of the piosphere. However, they are also susceptible to decline in quantity as a result of increased grazing pressure because their mean presence declines with proximity to the piospheres. Thus, their ability to provide browse under high grazing pressure may be limited. Pastoralists in Amboseli Kenya, when building kraals (bomas) have been found to clear trees with $20 \mathrm{~cm}$ basal diameter and those less within $150 \mathrm{~m}$ from the boma (Muchiru et al. 2008); making such trees highly susceptible to cut and burn. In Karamoja, clearance at the protected kraal is mandatory not only for security reasons but also for the establishment of kraals because woody plants, particularly thorny acacia, provide building materials. On the other hand, when establishing waterholes, woody plant clearance is not as widespread as in protected kraals (personal observations). Our results corroborate the findings of ChamailleJammes et al. (2009) who observed lower woody cover 
average at close proximity to the piosphere with an outward increase. Further, like in the findings of Mphinyane (2001) in which Acacia gerrardii's density increased with distance away from the piosphere (cattle post), several woody species (e.g. Acacia drepanolobium, Acacia xanthopholea, Maerua pseudopetalosa and Triumfetta annua) were found to increase outward with the gradient distance. However, it contrasts with the findings of Sternberg (2012) in a study in the Mongolian plateau which showed that vegetation was greater near water points and decreased with distance.

Some species such as Acacia nilotica, Acacia senegal, Ocimum canum, Lannea humilis, Solanum incanum and Leucas martinicensis however decreased with increase in gradient distance from waterholes. Acacia nilotica has been identified as type III increaser species (Strohbach 2000). In the Karamoja piospheres, these species that decreased away from the piosphere revealed a limited abundance in the rangeland. This corroborates species-wise findings of Strohbach (2000) in northern Oshikoto region of Namibia and Muchiru et al. (2008) in Amboseli, Kenya. Further, Acacia nilotica has been observed as a significant threat to native vegetation, as it leads to decline in cover and abundance of native species (Howes and McAlpine 2008). In Karamoja, we observed that Acacia nilotica had formed a bush and there was significant deficiency of herbaceous understory as well as other woody plants. A few tufts of both woody and herbaceous plants existed at the base of Acacia nilotica trees, but these were not accessible to livestock for grazing. Consequently, livestock, mainly goats and sheep, foraged on the outside branches up to their stretch height.

Notably, where mature Acacia nilotica trees existed (particularly along river banks), goats and sheep foraged on their pods. The negative slope observed with respect to Acacia senegal can be explained by traditional conservation practice in which it is preserved for resin locally used for its incense (no large commercial use in Karamoja has been documented as for example Sudan, e.g. Eisa et al. 2008). We also observed that around some waterholes, Acacia senegal was allowed to form a bush canopy to shield the dam from strong winds. According to Eisa et al. (2008), Acacia senegal's availability is affected by fires that kill off seedlings and damage trees. In the case of Karamoja, cutting off large branches (in this case for establishing kraals/bomas), defoliation by goats and camels, and attack from fungi and termites can be probable explanations for the negative slope observed along the gradient distance; this needs further scientific investigation. Herbs with woody stokes such as Solanum incanum had a negative slope indicating a high mean density of plants in proximity to the piospheres. The high abundance of Solanum incanum in disturbed patches has been documented in Ithala Game Reserve, KwaZulu-Natal, and with close proximity to the watering point in southern Kalahari Duneveld, respectively (Hebbelmann 2013; Horn 2008).

\section{Conclusions}

This study has shown that piosphere development in Karamoja is clustered into eight density blocks. This pattern of piosphere development is reactionary, oscillating with major drought and security events in the region. We also observed a disproportionate spatial distribution of livestock water sources in the sub-region. Piosphere health is generally poor characterised by a persistence of high grazing and trampling intensity and existence of soil erosion. Consequently, differentiated localized degradation at the piosphere sacrifice zones is evident. Gradient distance has had differentiated influence on herbaceous and woody plant species around the piosphere zones, leading to emergence of decreaser and increaser herbaceous and woody species along the grazing gradient. Given the clustering and disproportionate spatial distribution of piospheres, it is only a matter of time before the ripple effect of piosphere degradation engulfs the subregion. Protected kraals present a unique situation because their residence time at a location is shorter than that of waterholes (constructed waterholes will be permanent); thus, the mobility nature of these piospheres has potential to allow locations to recover and create 'islands of fertility' arising from livestock dung. We are of the view that an inquiry be extended into the nutrient distribution along the piosphere gradient for an extended distance to determine whether plant species variation changes with soil nutrients and landscape. Further, there is need to compare herbaceous and woody species abundance in former protected kraals and abandoned kraals to analyse plant recolonization in the piosphere zones. It will also be crucial to model piosphere dynamics structuring of herbaceous and woody plant composition and abundance in the region, because these will have influence on forage availability dynamics in the region.

\section{Additional files}

Additional file 1: Annex A: Relationship between grazing intensity, plant height and distance at the waterholes and protected kraals piospheres.

Additional file 2: Influence of gradient distance on different grass species at the waterholes in Karamoja.

Additional file 3: Influence of gradient distance on different woody species at the waterholes in Karamoja.

Additional file 4: Influence of gradient distance on different grass species at the protected kraals.

Additional file 5: Influence of gradient distance on different woody species at the protected kraals in Karamoja.

\section{Competing interests}

The authors declare that they have no competing interests.

\section{Authors' contributions}

EA carried out fieldwork, collated the data, and drafted the manuscript. OW, LM and MM provided overall guidance in the conceptualization of the research, data collection approaches and analysis process. JRST provided technical guidance on species classification and PCA analysis. All authors read and approved the final manuscript. 


\section{Acknowledgements}

This study was funded in part by a grant to Makerere University by the Carnegie Corporation of New York and Makerere University. Additional funding was provided by Regional Universities Forum for Capacity Building in Agriculture (RUFORUM).

\section{Author details}

${ }^{1}$ Department of Environmental Management, Makerere University, P.O. Box 7062, Kampala, Uganda. ${ }^{2}$ Regional Universities Forum for Capacity Building in Agriculture (RUFORUM), P.O. Box 16811, Kampala, Uganda. ${ }^{3}$ Department of Land Resource Management and Agricultural Technology, University of Nairobi, P.O. Box 29053-00625, Nairobi, Kenya. ${ }^{4}$ Department of Agricultural Economics, University of Nairobi, P.O. Box 29053-00625, Nairobi, Kenya. ${ }^{5}$ Department of Geography, Geo-informatics and Climatic Sciences, Makerere University, P.O. Box 7062, Kampala, Uganda.

\section{Received: 22 January 2015 Accepted: 27 June 2015}

Published online: 20 July 2015

\section{References}

Abule, E, GN Smit, and HA Snyman. 2005. The influence of woody plants and livestock grazing on grass species composition, yield and soil nutrients in the Middle Awash Valley of Ethiopia. Journal of Arid Environments 60: 343-358.

Abule, E, HA Snyman, and GN Smit. 2007. Rangeland evaluation in the middle Awash valley of Ethiopia: I. Herbaceous vegetation cover. Journal of Arid Environments 70(2): 253-271.

Adler, PB, and SA Hall. 2005. The development of forage production and utilization gradients around livestock watering points. Landscape Ecology 20(3): 319-333.

Andrew, MH. 1988. Grazing impact in relation to livestock watering points. Trends in Ecology and Evolution 3: 336-339.

Ash, A, J Gross, and MS Smith. 2004. Scale, heterogeneity and secondary production in tropical rangelands. African Journal of Range and Forage Science 21(3): 137-145.

Awa, DN, A Njoya, YM Logtene, JA Ndomajdi, J Onana, A Asongwed-Awa, et al. 2002. Livestock production systems in semi-arid savannah of the Central African sub region. Actes du colloque, 27-31 mai 2002, Garoua, Cameroun.

Bailey, DW, and FD Provenza. 2008. Mechanisms determining large-herbivore distribution. In Resource ecology, 7-28. Netherlands: Springer.

Barber, JP. 1962. The Karamoja District of Uganda: A pastoral people under colonial rule. The Journal of African History 3(1): 111-124.

Barboni, D, L Bremond, and R Bonnefille. 2007. Comparative study of modern phytolith assemblages from inter-tropical Africa. Palaeogeography, Palaeoclimatology, Palaeoecology 246: 454-470.

Brooks, ML, JR Matchett, and KH Berry. 2006. Effects of livestock watering sites on alien and native plants in the Mojave Desert, USA. Journal of Arid Environments 67: 125-147.

Chamaille-Jammes, S, H Fritz, and H Madsikanda. 2009. Piosphere contribution to landscape heterogeneity: A case study of remote-sensed woody cover in a high elephant density landscape. Ecography 32: 871880.

Derry JF. 2004. Piospheres in semi-arid rangeland: Consequences of spatially constrained plant-herbivore interactions. Unpublished PhD thesis. University of Edinburg, UK. pp323 http://www.era.lib.ed.ac.uk/bitstream/handle/1842/ 600/JF\%20Derry\%20PhD\%20thesis\%202004.pdf?sequence=19.

Du Toit, JCO. 2009. Early survival and growth of vegetatively propagated indigenous grasses in a clear-felled timber plantation in KwaZulu-Natal, South Africa. African Journal of Range and Forage Science 26(2): 97-101.

Dune, T, D Western, and WE Dietrich. 2011. Effects of cattle trampling on vegetation, infiltration, and erosion in a tropical rangeland. Journal of Arid Environments 75: 58-69.

Dyer, N, S Omondi, and M Wantsusi. 2008. Securing pastoralism in East and West Africa: Protecting and promoting livestock mobility. Karamojong Cluster Desk review. Consultancy Report. Available from: www.pubs.iied.org/pdfs/G03036.pdf (Accessed on 20th June, 2014).

Eisa, MA, M Roth, and G Sama. 2008. Acacia senegal (gum Arabic tree): Present role and need for future conservation/ Sudan. Hohenheim, Germany: Deutscher Tropentag.

Fusco, M, J Holechek, A Tembo, A Daniel, and M Cardenas. 1995. Grazing influences on watering point vegetation in the Chihuahuan desert. Journal of Range Management 48: 32-38.
Government of Uganda (GoU). 2007. Karamoja Integrated Disarmament and Development Programme. Creating conditions for promoting human security and recovery in Karamoja, 2007/2008-2009/2010, 1-141. Kampala Uganda: Office of the Prime Minister (OPM).

Gray, S. 2013. The experience of violence and pastoralist identity in Southern Karamoja. In Changing identifications and alliances in North-east Africa: volume II: Sudan, Uganda, and the Ethiopia-Sudan borderlands, vol. 3, ed. G Schlee and EE Watson(eds). Changing Identifications and Alliances In North-east Africa: Volume II: Sudan, Uganda, and the Ethiopia-Sudan Borderlands, Vol. 3. Berghahn Books.

Gray, S, M Sundal, B Wiebusch, MA Little, PW Leslie, and IL Pike. 2003. Cattle raiding, cultural survival, and adaptability of East African pastoralists. Current Anthropology 44: S3-\$30.

Hebbelmann, L. 2013. Changes in adult female white rhino seasonal home ranges in relation to variation in food quality and availability, 1-82. University of KwaZulu-Natal, South Africa: MSc. Thesis.

Horn, A. 2008. Impact of different forms of land use on the vegetation of the Southern Kalahari Duneveld, 1-164. Krämer aus Hannover: PhD Thesis, vorgelegt von Anne Horn geb.

Hoshino, A, Y Yoshihara, T Sasaki, T Okayasu, U Jamsran, T Okuro, and K Takeuchi. 2009. Comparison of vegetation changes along grazing gradients with different numbers of livestock. Journal of Arid Environments 73(6): 687-690.

Howes, AL, and CA McAlpine. 2008. The impact of artificial watering points on rangeland biodiversity: A review, DKCRC Working Paper 15, The WaterSmart ${ }^{\text {TM }}$ Literature Reviews, 1-34. Alice Springs: Desert Knowledge CRC.

James, CD, J Landsbery, and SR Morton. 1999. Provision of watering points in the Australian arid zone: a review of effects on biota. Journal of Arid Environments 41(1): 87-121.

Knighton, B. 2006. Can notions of common property and the common good survive? The consequences of classical economics for Karamojong nomadic pastoralists. IASCP Conference 19-23: 6.06.

Landman, M, DS Schoeman, AJ Hall-Martin, and GIH Kerley. 2012. Understanding long-term variations in an elephant piosphere effect to manage impacts. PloS ONE 7(9): e45334.

Landsberg, J, CD James, J Maconochie, AO Nicholls, J Stol, and R Tynan. 2002. Scale-related effects of grazing on native plant communities in an arid rangeland region of South Australia. Journal of Applied Ecology 39: 427-444.

Lange, RT. 1969. The piosphere: Sheep track and dung patterns. Journal of Range Management 22: 396-400.

Linstädter, A, B Kemmerling, G Baumann, and H Kirscht. 2013. The importance of being reliable - Local ecological knowledge and management of forage plants in a dryland pastoral system (Morocco). Journal of Arid Environments 95: $30-40$.

Macchi, L, and HR Grau. 2012. Piospheres in the dry Chaco. Contrasting effects of livestock puestos on forest vegetation and bird communities. Journal of Arid Environments 87: 176-187.

Mansour, K, O Mutanga, T Everson, and E Adam. 2012. Discriminating indicator grass species for rangeland degradation assessment using hyperspectral data resampled to AISA Eagle resolution. ISPRS Journal of Photogrammetry and Remote Sensing 70: 56-65.

Manthey, M, and J Peper. 2010. Estimation of grazing intensity along grazing gradients - The bias of nonlinearity. Journal of Arid Environments 74: 1351-1354.

Moreno García, CA, J Schellberg, F Ewert, K Brüser, P Canales-Prati, A Linstädter, RJ Oomen, JC Ruppert, and SB Perelman. 2014. Response of communityaggregated plant functional traits along grazing gradients: Insights from African semi-arid grasslands. Applied vegetation science 17(3): 470-481.

Mphinyane, WN. 2001. Influence of livestock grazing within piospheres under free range and controlled conditions in Botswana. University of Pretoria: PhD Thesis.

Mubiru, DN. 2010. Climate change and adaptation options in Karamoja, 1-62. Kampala Uganda: A report submitted to FAO and EU.

Muchiru, AN, D Western, and RS Reid. 2008. The impact of abandoned pastoral settlements on plant and nutrient succession in an African savanna ecosystem. Journal of Arid Environments 73: 322-331.

Mugerwa, S, S Kayiwa, and A Egeru. 2014. Status of livestock water sources in Karamoja sub-region, Uganda. Resources and Environment 4(1): 58-66.

Nakileza, B, ENB Nsubuga, M Tenywa, and A Lwakuba. 1999. Rethinking natural resource degradation in semi-arid sub-Saharan Africa: A review of soil and water conservation research and practice in Uganda, with particular emphasis on the semi-arid areas. Soil and Water Conservation Society of Uganda (SWCSU), 88. Uganda: University of Makerere. 
Oba, G. 2012. Harnessing pastoralists' indigenous knowledge for rangeland management: Three African case studies. Pastoralism: Research, Policy and Practice 2: 1.

Oluwole, F, J Sambo, and D Sikhalazo. 2008. Long-term effects of different burning frequencies on the dry savannah grassland in South Africa. African Journal of Agricultural Research 3(2): 147-153.

Powell, J. 2010. Karamoja: A literature review. A Saferworld Report, 1-36.

Rajabov, T. 2009. Ecological assessment of spatio-temporal changes of vegetation in response to piosphere effects in semi-arid rangelands of Uzbekistan, 1-36. Iceland: Land Restoration Training Programme, Final Report.

Riginos, C, and J Herrick. 2010. Monitoring rangeland health: A guide for pastoralist communities and other land managers in Eastern Africa, version II. Nairobi, Kenya: ELMT-USAID/East Africa. Available from: http://www.mpala.org/ Monitoring_Guide.pdf (Accessed on 15th August, 2014).

Rita, P, M Aninda, and DK Animesh. 2012. An updated overview on Cynodon dactylon (L.) Pers. IJRAP 3(1): 11-14.

Sasaki, T, T Okayasu, U Jamsran, and K Takeuchi. 2008. Threshold changes in vegetation along a grazing gradient in Mongolian rangelands. Journal of Ecology 96: 145-154

Shahriary, E, MW Palmer, DJ Tongway, H Azarnivand, M Jafari, and M Mohseni Saravi. 2012. Plant species composition and soil characteristics around Iranian piospheres. Journal of Arid Environments 82: 106-114.

Smet, M, and D Ward. 2006. Soil quality gradients around water-points under different management systems in a semi-arid savanna, South Africa. Journal of Arid Environments 64: 251-269.

Sternberg, T. 2012. Piospheres and pastoralists: vegetation and degradation in steppe grasslands. Human Ecology 40(6): 811-820.

Stites, E, D Akabwai, D Mazurana, and P Ateyo. 2007. Angering Akujù: Survival and suffering in Karamoja. A Report on Livelihoods and Human Security in the Karamoja Region of Uganda. Feinstein International Center, pp1-90 http://reliefweb.int/report/uganda/angering-akuj\%C3\%B9-survival-and-suffering-karamoja.

Stride, C. 1997. Distribution of grass species and attributes of grasses near a bore drain in a grazed semi-arid subtropical grassland. Australian Journal of Botany 45: 919-927.

Strohbach, BJ. 2000. Vegetation degradation trends in the northern Oshikoto Region: II. The Colophospermum mopane shrublands. DINTERIA 26: $63-75$.

Stumpp, M, K Wesche, V Retzer, and G Miehe. 2005. Impact of grazing livestock and distance from water source on soil fertility in southern Mongolia. Mountain Research and Development 25(3): 244-251.

Sundal, MB. 2009. Difficult decisions: Karamojong healing in conflict, 1-251. University of Kansas, USA: PhD Thesis.

Tarhouni, M, FB Salem, AO Belgacem, and M Neffati. 2010. Acceptability of plant species along grazing gradients around watering points in Tunisian arid zone. Flora-Morphology, Distribution, Functional Ecology of Plants 205(7): 454-461.

Teka, H, IC Madakadez, A Hassen, and A Angassa. 2013. Mineral lick-centered land-use and its effects on herbaceous vegetation in Southern Ethiopia. African Journal of Agricultural Research 8(46): 5872-5883.

Thomas, DSG, and C Twyman. 2004. Good or bad rangeland? Hybrid knowledge, science, and local understandings of vegetation dynamics in the Kalahari. Land Degradation and Development 15: 215-231.

Thrash, I, and JF Derry. 1999. The nature and modelling of piospheres: A review. Koedoe 42(2): 73-94.

Todd, SW. 2006. Gradients in vegetation cover, structure and species richness of Nama-Karoo shrublands in relation to distance from livestock watering points. Journal of Applied Ecology 43: 293-304.

Van Strien, A, Pannekoek, J Hagemeijer W, and Verstrael, 2004. A loglinear Poisson regression method to analyse bird monitoring data. Bird, 1995: 33-39

Washington-Allen, RA, TG Van Neil, R Douglas Ramsey, and NE West. 2004. Remote sensing-based piosphere analysis. GIScience and Remote Sensing 41(2): 136-154

Wesuls, D, M Pellowskia, S Suchrowb, J Oldelanda, F Jansenc, and J Denglera. 2013. The grazing fingerprint: Modelling species responses and trait patterns along grazing gradients in semi-arid Namibian rangelands. Ecological Indicators 27: 61-70.

$\mathrm{Yu}, \mathrm{H}$, and B Wu. 2010. Research progress on piospheres. The Journal of Applied Ecology 21(2): 523-532.

Zemmrich, A, C Oehmke, and SM Greifswald. 2007. A scale-depending grazing gradient in an Artemisia-desert steppe? A case study from western Mongolia. Basic and Applied Dryland Research 1: 17-32.

\section{Submit your manuscript to a SpringerOpen ${ }^{\circ}$ journal and benefit from:}

- Convenient online submission

- Rigorous peer review

- Immediate publication on acceptance

- Open access: articles freely available online

- High visibility within the field

- Retaining the copyright to your article

Submit your next manuscript at $>$ springeropen.com 